\title{
Issues in Translating Cultural Terms between English and Malay: A Comparative Analysis
}

\author{
Mohammed H. AlAqad ${ }^{1 *}$, Mohammad Ali Al-Saggaf ${ }^{2}$
}

${ }^{1}$ Management and Science University, MALAYSIA

${ }^{2}$ Xiamen University, MALAYSIA

*Corresponding Author: alakkadmohmad@yahoo.com

Citation: AlAqad, M. H., \& Al-Saggaf, M. A. (2021). Issues in Translating Cultural Terms between English and Malay: A Comparative Analysis. Pedagogical Research, 6(4), em0106. https://doi.org/10.29333/pr/11272

\section{ARTICLE INFO}

Received: 31 Jul. 2021

Accepted: 29 Sep. 2021

\begin{abstract}
This study aims to examine the challenges in translating Malay cultural terms into English, and to determine practical procedures to overcome these challenges. The translation challenges in translating Malay cultural terms into English raised due to some factors; sound, lexis, grammar, and style. Both English and Malay originate from different language families and systems. While the former is from a Germanic family, the latter is an Austronesian origin, therefore, this results in a wide gap between their grammatical systems which causes considerable problems for some learners. Thus, the researcher thoroughly introduces the issue and analyses the findings by collecting data from books, conversation and social media. The study targets English and Malay cultural terms, more specifically Bruneian Malay and to achieve these targets the study employes Mona Baker's equivalence typology to fulfil the research objectives. Consequently, this research paper seeks to find practical solutions for translators who are facing the similar challenges in translation.
\end{abstract}

Keywords: English and Malay translation, cultural challenges, comparative analysis

\section{INTRODUCTION}

The concept of culture terms in this study is very complex term to define. However, it is well acknowledged that the concept of culture is an essential division in all aspects and it plays a significant role in the human communication. According to Raymond Williams (1998, p. 48-56), the definition of 'culture' has three classifications: ideal definition, documentary definition and social definition. Although they come in different classifications, these three are quite similar to each other. In which can be concluded that culture is merely just an activity and tradition that was passed down from our ancestors in which deeper in the century, the concept will eventually evolve due to time and growth. Alternatively, the concept of culture according to anthropologist Paul Bohannan (1988), it is merely the act of 'art' or the behaviour and pattern of human beings. In this regard, it is clearly demonstrated that the concept of culture is quite complicated, but what about understanding the different culture itself; how do non-native speakers understand the cultural terms and how do they explain such cultural terms or behaviour.

There are many concerns that people face when they attempt to translate certain cultural specific terms (CST) to the nonlocals and sometimes also to their own locals. Native people might understand the cultural specific terms, but they might not able to explain it clearly or even translate the terms faithfully because the CST does not exist in the target language (TL). Understanding a culture is one agenda; however, explaining certain cultural terms to the non-natives is another. 'Culture' as mentioned above, is the behaviour that was derive from our ancestors, which then eventually evolve throughout the century. Some cultural terms and cultural behaviour are also loaned from other culture as well, which makes it further challenging to justify certain cultural behaviour or lexes. On account of the previous statement, this thesis is designed to compare and contrast the disputes in translating English and Malay cultural terms in which the research question and statement problem will be further discussed below. In relation to that, this thesis will establish its framework by analyzing the key questions: what are the issues in translating Malay and English cultural terms, and what are the practical procedures to overcome these challenges.

The researcher's personal experience in translating a cultural specific terms (CSTs) has motivated her to conduct this research. In an attempt to explain and translate CST to a second and third party, the researcher observed that there was an issue raised regarding losing the significance of the source text message (ST) in the target text (TT). Thus, the researcher finds her passion for finding practical solutions to this issue and furthering her knowledge and understanding on this topic. The purpose of this study is to define the different issues when translating cultural specific terms especially in today's perspective. Other than that, this study aims to observe how easy or how difficult it is to translate the cultural terms and determine their solution to overcome these difficulties. 


\section{Research Objectives}

The objectives of this study are:

1) to identify the issues faced in translating Malay cultural terms into English.

2) to determine practical procedures to overcome these issues.

\section{LITERATURE REVIEW}

Literature review is an overview of translation and the concept that justifies the important aspects in translation theory and as well as the cultural implications which will be instigated towards this research. Moreover, the purpose of this chapter is to identify the features of this comparative analysis and to identify any current knowledge towards the topic. The conceptual framework that the researcher has used during the process of research is Mona Baker's equivlence. This is because, Mona Baker discussed the lack of equivalence at word level and what a translator should do when there is no identical meaning as the SL word in her book called, 'In Other Words' (1992). She mentioned that Non-equivalence at a word level defines as when the TT has no direct equivalent meaning as the ST. Baker also examined the common problems of non-equivalence at a word level such:

a) Culture specific concept: This concept occurs when the SL word may express a terminology that is non-existence in the TL. This could vary from religion belief, social custom or even a type of food. This type of concept is also known as 'culturespecific'.

b) The SL concept is not lexicalised in the TL: Some SL word may occur in the TL culture but is not lexicalised. Baker gave an example with the word 'savoury', the word has no equivalent in many languages but the expressing the concept is easy to rationalise.

c) The SL word is semantically complex: The most common problem in translation is when the SL word is semantically complex. This means that one word could consist of a single morpheme which can express a complex set of definitions.

d) The SL and TL make different distinctions in meaning: The TL sometimes make fewer or more distinctions in significance than the SL.

e) The TL lacks a superordinate: This means that the TL have specific words (hyponyms) with no general word (superordinate) in the semantic field.

f) The TL lacks a specific terms (hypnonym): This is a very common problem when translating because languages usually have general words (superordinates) but it lacks specific hyponyms.

g) Differences in physical or interpersonal perspective: Baker presented that physical perspective may be of more important in one language than it is in another.

h) Differences in expressive meaning: There may be a TL word which has a similar propositional definition as the SL word, however it might have a different significant meaning.

i) Differences in form: When there is no equivalent in the TL for a particular form in the ST. Certain suffixes and prefixes that deliver the propositional and other types of definition in English usually does not have a direct equivalents in other languages.

j) Differences in frequency and purpose of using specific forms: When a particular method does have an equivalent in the $\mathrm{TL}$, there might be a difference in the occurrence with how it is used or the purpose of it.

k) The use of loan words in the ST: When a word or expression is borrowed into another language, we cannot predict or control the meaning.

With this, Mona Baker proposed a strategies used by professional translators for dealing with these types of problems in which is stated below.

A) Translation by a more general word (superordinate)

B) Translation by a more neutral/less expressive word

C) Translation by cultural substitution

D) Translation using a loan word or loan word plus explanation

E) Translation by paraphrase using a related word

F) Translation by paraphrase using unrelated words

G) Translation by omission

H) Translation by illustration

Abidin et al. (2016) have proposed a research on how the Malay language does not have different types of tenses to indicate past, present, or future time unlike the English language. In Malay, the unique procedure to represent time reference is to use 'telah' for any past events and 'akan' for future events. Despite the uniqueness, this can also be a problem faced by Malay language learners to construct their own sentences. Therefore, this research focuses on the insight of Malay language learners and as well as the construction involving time references. 
Table 1. Data collection

\begin{tabular}{|c|c|c|c|c|}
\hline Item & Person & Slang & Interjection & Metaphor \\
\hline SL & \multicolumn{4}{|c|}{ Number of Lexes to be Collected and Translated } \\
\hline English & 2 & 2 & 2 & 2 \\
\hline Malay & 2 & 2 & 2 & 2 \\
\hline & & & Total & 18 \\
\hline
\end{tabular}

Table 2. Finalised data collection (English)

\begin{tabular}{ll}
\hline & SL \\
\hline Categories & English \\
\hline Person & $\begin{array}{l}\text { 1. Grandmother } \\
\text { (Titles, honorary titles, family member, etc.) }\end{array}$ \\
\hline \multirow{2}{*}{ Slangs } & 2. Prince \\
\hline \multirow{2}{*}{ Interjection } & $\begin{array}{l}\text { 1. Shoot. } \\
\text { Metaphor }\end{array}$ \\
\hline \multirow{2}{*}{ 2. What's up? } \\
\hline
\end{tabular}

Table 3. Finalised data collection (Malay)

\begin{tabular}{ll}
\hline & SL \\
\hline Categories & Malay \\
\hline Person & 1. Duli Yang Maha Mulia Paduka Seri Baginda--- \\
(Titles, honorary titles, family member, etc.) & 2. Her \\
\hline \multirow{2}{*}{ Slangs } & $\begin{array}{l}\text { 1. Elek } \\
\text { Interjection }\end{array}$ \\
\hline \multirow{2}{*}{ Metaphor } & 2. Ons x ons \\
& $\begin{array}{l}\text { 1. Bah } \\
\text { 2. Nah }\end{array}$ \\
\hline
\end{tabular}

Table 4. Sample of cultural terms between English and Malay

\begin{tabular}{lll}
\hline Category & SL & TL \\
\hline Person & 1. Grandmother & 1. Nenek (Standard Malay) \\
(Titles, honorary titles, family member, etc.) & & 1.1 Nini (Brunei Malay) \\
\hline & 2. Prince & 2. Putera \\
\hline
\end{tabular}

\section{METHODOLOGY}

In this section, the researcher uses a qualitative method to conduct this comparative analysis. The qualitative data has been gathered through the collection of cultural lexes from books, newspaper, and daily conversation (i.e., slangs, interjection, etc.). This study targets English and Malay cultural terms, more specifically Malay Brunei. To widen her data collection, she will be collecting data through daily conversation and as well as newspaper for cultural lexes which later in the research, she will compare and contrasts the difficulties in translating the cultural lexes. The researcher has collected all necessary data for her to analyse. With this being said, the researcher has to collect all the cultural lexes from newspaper and daily dialogue. Once the data collection reaches the desired amount, the researcher analyses both languages side by side and focuses on the difficulties while translating the lexes and as well as to determine whether the significance of the cultural lexes has gained or loss it's meaning in the TT. With this, the researcher hopes that by the end of this paper, she will achieve her research objectives.

The researcher gathered 2 lexes for each category, 8 lexes from every language and analysed the findings thoroughly. Moreover, she will collect 2 lexes and it is designed in this approach so that there are enough terminologies to be compared and contrasts. Table 1 illustrates the data collection.

\section{DATA ANALYSIS AND FINDINGS}

All lexes were collected randomly through newspapers and news outlet such as BBC News, Borneo Bulletin, Pelita Brunei and as well as collected from social media such as TikTok, Instagram and WhatsApp to get an up-to-date slang.

The finalised collected data is illustrated in Tables 2-4.

From the data on Table 4, the researcher finds it very easy to translate as both of the ST are at a word level, because the two ST's meaning of a single lexes and expression. Hence the simple and very straightforward translation. Moreover, on the TL column, it is clear that there is another alternative for "nenek" as "nini". This is because in some country such as Brunei Darussalam, locals 
Table 5. Cultural terms- 1

\begin{tabular}{lll}
\hline Category & SL & TL \\
\hline Slang & 1. Shoot & 2. Alamak! \\
\hline & 2. What's up? & 2. Apa khabar? \\
\hline
\end{tabular}

Table 6. Cultural terms- 2

\begin{tabular}{lll}
\hline Category & SL & TL \\
\hline Interjection & 1. Wow! & 1. Wah! \\
\hline & 2. Ouch! & 2. Aduh! \\
\hline
\end{tabular}

Table 7. Cultural terms- 3

\begin{tabular}{lll}
\hline Category & SL & TL \\
\hline Metaphor & $\begin{array}{c}\text { 1. My knight in shining } \\
\text { armour }\end{array}$ & $\begin{array}{c}\text { 1. (Literal Translation): Kesatria saya dalam baju besi yang } \\
\text { bersinar } \\
\text { Frasa ini menggambarkan sebagai seseorang yang } \\
\text { menyelamatkan anda dalam keadaan buruk }\end{array}$ \\
\hline & & 2. (Literal Translation): Memukul tepat \\
& & Frasa ini memaksudkan tentang melakukan sesuatu dengan \\
& & tepat. \\
\hline
\end{tabular}

Table 8. Cultural terms- 4

\begin{tabular}{lll}
\hline Category & SL & \multicolumn{1}{c}{ TL } \\
\hline Person & 1. Duli Yang Maha Mulia & 1. His Majesty \\
(Titles, honorary titles, family member, etc.) & Paduka Seri Baginda--- & 1.1 His Majesty Duli Yang Maha Mulia Paduka Seri Baginda-- \\
\hline & 2. Dia & 2. Her/Him \\
\hline
\end{tabular}

Table 9. Cultural terms- 5

\begin{tabular}{lll}
\hline Category & SL & TL \\
\hline Slangs & 1. Elek & 1. Relax \\
\hline & 2. Ons x ons & 2. Equivalent to: \\
& & - Are we still on (for the plan)? \\
& & - You in (joining)? \\
& & ('x' is pronounces as 'tak' in Malaysia, in which could also mean no) \\
\hline
\end{tabular}

would call their grandparents as "nini" just how the Indonesians would call their grandfather as "kakek". All in all, the standard translation for grandmother is "nenek" while the standard translation for prince is "putera".

On Tables 7 and 8, to translate successfully, the researcher has followed Mona Baker's technique which is using cultural substitution and/or using a related word. With this, the researcher tries to relate the SL culture into the TL culture. Therefore, the researcher has decided to see what the equivalent is of the slang "shoot" and "what's up?" and the interjections of "wow" and "ouch!" in Malay. In which the researcher concluded these lexes as "Alamak" because the interjection of "shoot" is the expression of getting angry or forgetting to do something, in which is the equivalent to "Alamak!"

Lastly, the most difficult cultural terms to translate is the the metaphor. Firstly, the researcher tried her best use a related words or a cultural substitution. However, after many failed attempt to substitute it culturally, the researcher has no choice but again, to follow Mona Baker's technique to just explain what the sentence mean.

Another difficulty that occurred in translating Malay language is that majority of the Malay lexes has a religious sense to it, in which, makes it more difficult to translate because as a translator, it is logical to be careful with this topic to avoid any misunderstanding as it is a sensitive topic to discuss about. For example, on Table 8, it is an honorary (royal) title. Majority of Malay's royal title have a hint of religion within. With this, the nearest equivalence to this title is 'His Majesty'. Many Malay speakers have always thought that the title can be misleading, as if it is saying that royalties are in the same level as God, but many fails to realise the deeper meaning of the title because it uses classic Malay language. To explain thoroughly as to why the royal title is considered as sensitive, below is the explanation of the full title.

\section{Duli Yang Maha Mulia Paduka Seri Baginda}

This title is mainly used by the Monarch such as the king. The word 'Duli' means ashes in classic Malay language. Adding to that, the word 'yang' which translates to 'that' or 'which' also means 'owned by' and lastly the words 'Maha Mulia' refers to God. Overall, Duli Yang Maha Mulia means ash that is owned by Allah (God). In other words, no matter how high their position is in this world, or how powerful they are to humans, but to God, they are just a dust in compared to him (God). Moreover, 'Paduka' translates to sandal, 'Seri' translates to light and 'Baginda' refers to the Prophet Muhammad SAW (pbuh). In result, this second half of the title refers to no matter how wealthy the monarch is or how powerful he is, they are just a slipper on the feet of the Prophet (pbuh), the messenger of Allah. This concludes that, nobody can be on the same level as God and Prophets (2018). 
Table 10. Cultural terms- 6

\begin{tabular}{lll}
\hline Category & SL & TL \\
\hline Interjection & 1. Bah & $\begin{array}{l}\text { 1. Okay } \\
\text { (Mainly used in Borneo: Brunei, Sabah, Sarawak) }\end{array}$ \\
\hline & 2. Nah & $\begin{array}{l}\text { 2. Here } \\
\text { (usually used with anger tone) }\end{array}$ \\
\hline
\end{tabular}

Table 11. Cultural terms- 7

\begin{tabular}{lll}
\hline Category & SL & TL \\
\hline Metaphor & 1. Lain dulang, lain & 1. (Literal Translation): Another leg another tray \\
& kakinya. & This metaphor describes as how different people have different hearts (intention) \\
\hline 2. Orang tua itu tidur-tidur & 2. (Literal Translation): \\
& ayam. & That old man is sleeping hen. \\
& This metaphor describes as the old man sleeping soundly like a 'chicken' \\
\hline
\end{tabular}

Table 12. Cluster of cultural terms

\begin{tabular}{llll}
\hline Text No. & SLT (English) & TLT (Malay) & Technique used \\
\hline 1 & Grandmother & $\begin{array}{l}\text { Nenek } \\
\text { Nini (Mainly used in Brunei) }\end{array}$ & $\begin{array}{l}\text { Superordinate/ } \\
\text { related word }\end{array}$ \\
\hline 2 & Prince & Putera & Superordinate \\
\hline 3 & Shoot. & Equivalent to Alamak! & Cultural substitution \\
\hline 4 & What's up? & Apa khabar? & Using a related word \\
\hline 6 & Wow! & Wah! & Using a related word \\
\hline 7 & My knight in shining armour & Aduh! & Using a related word \\
\hline 8 & Hits the bullseye & yang menyelamatkan anda dalam keadaan buruk & n/a - merely an explanation \\
\hline
\end{tabular}

Same as to the data on Tables 7 and 8, the researcher has also put the same techniques of translation into the SL's interjection and slang (Tables 11 and 12). However, the only difference is that majority of Malay slang is derived and borrowed from English, and it also includes code mixing between both languages, whereas if the SL is English, the slang is not rooted from other languages. In which, the researcher finds it very interesting to translate. However, the researcher also had to give a short explanation of what the interjection and slang is just in case the readers might not understand.

Same as the previous, the translator tried to relate the metaphors/imagery into the TL's culture. However, after several failed attempts, the researcher has concluded to include an explanation of the sentences.

While translating the Malay and English cultural terms, the researcher has found a couple of problems that were similar to Mona Baker's (1992) non-equivalence at a word level. The most difficult category to translate was of course, metaphor. This is because metaphor carries a figure of speech to give off a rhetorical result which makes it more complex to translate into the target language because of the deeper meaning. For example, Table 7 and Table 11, the researcher had to explain the meaning behind the phrase because it would not make any logic to direct or literal translate it alone without having any further explanation. Moreover, if the researcher were to leave the results as a literal translation alone, it would not look visually pleasant to the readers' eyes. The other problem in translating cultural terms has already mentioned in Table 8.

With this, the researcher has followed Mona Baker's strategies to overcome any translation problem. Majority of the time, the researcher has used translation using a loan word plus explanation. For instance, for all metaphor in Malay and English language, there is no cultural equivalence to be found when it comes to translating the phrases. With this, the only solution is to explain what the ST means in the TT, so the readers are able to understand what it means instead having to read the literal translation. Other than that, take a look on Table $\mathbf{5}$ for slangs. The majority of the Malay slangs today are derived or borrowed from the English language, with this, the researcher/translator have decided to use translation by cultural substitution that was also mentioned by Mona Baker. This is when the translator relates the ST (Elek, ons $x$ ons) to the TT and give the most similar example that may exist in the TL's culture.

All in all, when it comes to translating cultural terms, the best way is to leave it as it is (when there is no equivalence in the TL's culture) or have an explanation alongside the translation, so the readers are able to understand clearer.

\section{DISCUSSION}

The researcher will discuss the key findings such as the patterns of distribution, the discussion of the research questions and as well as the recommendations for the aspiring translators. The researcher hopes to provide a clearer understanding to the readers on the difficulties in translating cultural terms as it can be very complex due to the sensitivity of the subject. The following table illustrates the patterns of distribution that has occurred while conducting this research. The purpose of this table to present the comparison of the SLT, TLT and the techniques used to see whether there is a reoccurring pattern. 
Table 13. Pattern of cultural terms

\begin{tabular}{|c|c|c|c|}
\hline $\begin{array}{l}\text { Text } \\
\text { No. }\end{array}$ & SLT (Malay) & TLT (English) & Technique used \\
\hline 1 & $\begin{array}{l}\text { Duli Yang Maha Mulia Paduka Seri } \\
\text { Baginda }\end{array}$ & $\begin{array}{l}\text { His Majesty or His Majesty Duli Yang Maha Mulia } \\
\text { Paduka Seri Baginda }\end{array}$ & Superordinate/ cultural substitution \\
\hline 2 & Dia & Her/Him & Superordinate \\
\hline 3 & Elek & Relax/Chill out & Paraphrase using related word/ cultural substitution. \\
\hline 4 & Ons $x$ ons & $\begin{array}{l}\text { Equivalent to: Are we still on (for the plan?) } \\
\text { You in (joining)? }\end{array}$ & Paraphrase using related word / Cultural Substitution. \\
\hline 5 & Bah & $\begin{array}{l}\text { Okay (Mainly used in Borneo island: Brunei, } \\
\text { Sarawak, Sabah) }\end{array}$ & Paraphrase using related word / Cultural Substitution. \\
\hline 6 & Nah & Here (you go) (Usuallly used with anger tone) & Paraphrase using related word / Cultural Substitution. \\
\hline 7 & Lain dulang, lain kakinya. & $\begin{array}{l}\text { This metaphor describes as how different people } \\
\text { have different hearts (intention) }\end{array}$ & n/a-merely an explanation \\
\hline 8 & Orang tua itu tidur-tidur ayam & $\begin{array}{l}\text { This metaphor describes as the old man sleeping } \\
\text { soundly like a chicken }\end{array}$ & n/a-merely an explanation \\
\hline
\end{tabular}

Table 14. Comparison of the two languages' equivalence level using Mona Baker's perspective on Equivalence

\begin{tabular}{lll}
\hline Categories & Equivalence Level (TLT: Malay) & Equivalence Level (TLT: English) \\
\hline Person & At word level & $\begin{array}{l}\text { Culture specific concept } \\
50 \% \text { Above word level }\end{array}$ \\
\hline Person & At word level & At word level \\
\hline Slangs & Pragmatic & Above word level \\
\hline Slangs & Pragmatic & Above word level \\
\hline Interjection & Pragmatic & Pragmatic \\
\hline Interjection & Pragmatic & Pragmatic \\
\hline Metaphor & Culture specific concept & Culture specific concept \\
\hline Metaphor & Culture specific concept & Culture specific concept
\end{tabular}

With Table 4, it can be concluded that the patterns in each respective language are similar yet different from each other. As clearly illustrated on Table 14, when it comes to translating English cultural terms, majority of the lexes includes a pragmatic equivalence in the TLT while simple and common words such and 'grandmother' and 'prince' is at a word level. Pragmatic equivalence defines as the way the texts are being used in a communicative situation which of course involves the writers, readers and cultural context. For example, the slang "what's up" is the equivalent to "apa khabar?" the reason as to why the researcher has concluded that this is a pragmatic equivalent, it is because the SL slang is only used on certain time and on certain people.

Other than that, take a look when translating a royalty title from Malay to English. The reason as to why it is $50 \%$ above word level and as well as it is counted as a culture specific concept it is because the deeper meaning as mentioned in the previous chapter, it consists of a religious background which therefore it does not exist in the TL, however, there is an equivalent to it, but it does not include the religious.

\section{Discussion of the Findings in Relation to Research Questions}

\section{Question 1}

"What are the issues in translating Malay and English cultural terms?"

Whilst translating the cultural terms, the researcher has found many issues regarding translating Malay and English cultural terms. First and foremost, every findings can be concluded and referred back to Mona Baker's equivalence typology. In compared to translating between Malay and English cultural terms, it can be concluded that translating Malay to English is much more difficult than translating from English to Malay, merely because Malay language carries a huge amount of religious context which may be difficult for translator to faithfully translate it into the target language without shifting the message as it can be very sensitive to the native speakers.

Other than that, while translating Malay cultural lexes to English, majority of the translation had to have a side explanation to clearly illustrate the meaning to the readers as because the Malay language, especially Malay slangs mostly carries a loan word from the English language, for example in Malay Brunei language, the word 'cali' translates to 'funny' this is because, 'cali' was derived from the famous English actor Charlie Chaplin who was known for his comical film. Other than that, the previous statement is also clear because signifying back to Table 14, it can be clearly seen that slangs in Malay were both loan words.

The findings also revealed that their inability to obtain the necessary knowledge regarding the cultural expression was due to a lack of research abilities.

Moreover, the other issue in translating Malay and English cultural terms is that any metaphorical or imagery phrases are almost imposible to find an equivalent in the target language as it cannot be translated directly or translate it word for word. When translating metaphors, the only solution is to explain what it means. There is nothing wrong with translating the phrases directly, but it would not look aesthetically pleasing to the eyes. 
Adding to the previous statements, when translating an idiom, imagery and so on, the most common problem in this is that there is a huge failure in achieving the equivalence in the TL. Although translating cultural terms may have its tribulations, there is always a solution in which will be discussed thorougly in the next section.

\section{Question 2}

"What are the practical procedures to overcome the issues?"

Despite the challenges occurred during translating the cultural terms, there is of course a solution to every problem. To unravel the the difficulty of translating cultural terms, the researcher as mentioned previously, has used Mona Baker's strategies that is widely used by professional translators when dealing with these types of problems. As illustrated on Tables 14 and 15 , it is clear as to which technique is used for the different categories for translating the cultural terms. As a translator translating cultural terms, it is important to understand the general context of the lexes, and once the translator has understand the context, it is important to recognise whether the lexes exist in the TL or not.

It result also illustrated that one of the reasons for their bad translation was the vast cultural divide between the two civilizations. According to Nida (1964), "no translation that strives to bridge a large cultural gap can hope to eradicate all traces of the foreign setting" (p. 167). The researcher recommends for further study to investigate more cultural terms between these two languages.

Once it is clear whether or not there is any problem in regard of the SL, the translator should understand thoroughly as to what type of problem is occuring in the process of translation. In regards of the previous statement and based on the conceptual framework in chapter 2, Mona Baker clearly stated the 11 different types of common problems in translating cultural terms. When the researcher is able to identify the type problem that the cultural lexes carries, it is important to try to relate the SL into the TL and do research about both TL and SL language before concluding that the lexes may not exist in the TL.

However, in this research, when the researcher is not able to find any at-word equivalence in the TL, the researcher has throroughly followed Mona Baker's problem-solving techniques that is used by many professional translator.

For example, the slang "what's up?" is a pragmatic equivalence to "Apa khabar?" in the Malay language. Therefore to translate this slang, the researcher paraphrased the term by using a related word. Mona Baker's strategies have helped a lot for the researcher to successfully overcome the issues in translating cultural terms.

\section{CONCLUSION}

Culture is a sensitive topic for some to discuss as it plays a huge role in ones life as it carries years and years of tradition that is passed on through generations. When translating such matters, it is important as a translator to not only hold the culture with care but also to remember not to change the whole cultural concept to a point where it is not the same in the SLT.

The researcher finds that unfamiliarity with both cultures and the improper translation techniques and strategies were major reasons for the translation challenges that followed by poor translation.

The findings also revealed that their inability to obtain the necessary knowledge regarding the cultural expression was due to a lack of research abilities. It also stated that one of the reasons for their bad translation was the vast cultural divide between the two civilizations. According to Nida (1964), "no translation that strives to bridge a large cultural gap can hope to eradicate all traces of the foreign setting" (p. 167). The researcher recommends for further study to investigate more cultural terms between these two languages.

Author contributions: All authors have sufficiently contributed to the study, and agreed with the results and conclusions.

Funding: No funding source is reported for this study.

Declaration of interest: No conflict of interest is declared by authors.

\section{REFERENCES}

Abdullah, S. (2014). Translating technical metaphors from English into Malay: Possibilities (and challenges). https://www.academia.edu/15335976/Translating_Technical_Metaphors_from_English_into_Malay_Possibilities_and_Chall enges

Al-Saggaf, M. A., Al-Aqad, M. H., \& Govindasamy, V. (2020). The key factors affecting English reading comprehension among Malaysian students. Psychology and Education Journal, 57(9), 2496-2503. https://doi.org/10.17762/pae.v57i9.629

Baker, M. (1992). In other words (A coursebook on translation). Routledge. https://doi.org/10.4324/9780203133590

Erikson Translation. (n.d.). Text expansion and contraction in translation. https://www.eriksen.com/text-expansion

Ghazala, H. (1995). Translation as problems and solutions: A coursebook for university students and trainee translators. ELGA Publication.

Ghazala, H. (2004). Stylistic-semantic and grammatical functions of punctuation in English-Arabic translation. Babel, 50(3), 230245. https://doi.org/10.1075/babel.50.3.03gha

Ginter, A. (2002). Cultural issues in translation. Routledge. 
Mansor, I. (2021). Explicitation in the intercultural communication of technical culture in Arabic-Malay translation of Rihlat Ibn Battuta. Journal of Intercultural Communication Research, 50(6), 556-570. https://doi.org/10.1080/17475759.2021.1884891

Merriam-Webster. (2020). Source language. https://www.merriam-webster.com/dictionary/source\%20language

Mukhlis, A. (2018). Maksud sebenar "DULI YANG MAHA MULIA" yang ramai tak tahu. https://www.memangwin.com/viral/win/maksud-duli-yang-maha-mulia/

Nasution, D. K., \& Syahputra, R. (2020). The impact of the translation techniques and ideologies on the quality of the translated text of Mantra Jamuan Laut from Malay language into English. In Proceeding International Conference on Language and Literature (IC2LC) (pp. 165-171). https://doi.org/10.33258/birci.v3i2.1024

Zainal Abidin, N., Ismayatim, W. A., \& Wai, Y. L. (2016). English to Malay (Bahasa Melayu) translation: Syntactical issues involving time reference. https://issuu.com/invention.journals/docs/j059058068

Zamin, A. A. M., \& Hasan, R. A. (2018). Errors in translation: A comparative study of noun phrase in English and Malay abstracts. Advances in Language and Literary Studies, 9(5), 17-23. https://doi.org/10.7575/aiac.alls.v.9n.5p.17 